\title{
Correction to: Catalytic pyrolysis of cellulose in sulfolane with some acidic catalysts
}

\author{
Haruo Kawamoto $^{1} \cdot$ Shinya Saito $^{1} \cdot$ Wataru Hatanaka $^{1} \cdot$ Shiro Saka ${ }^{1}$
}

Published online: 27 November 2018

(c) The Author(s) 2018

\section{Correction to: J Wood Sci (2007) 53:127-133 https://doi.org/10.1007/s10086-006-0835-y}

The article Catalytic pyrolysis of cellulose in sulfolane with some acidic catalysts, written by Haruo Kawamoto, Shinya Saito, Wataru Hatanaka and Shiro Saka, was originally published electronically on the publisher's internet portal (currently SpringerLink) on 2 December, 2006 without open access. With the author(s)' decision to opt for Open Choice the copyright of the article changed on 28 November, 2018 to $\odot$ The Author(s) 2018 and the article is forthwith distributed under the terms of the Creative Commons Attribution 4.0 International License (http://creativecommons.org/licen ses/by/4.0/), which permits use, duplication, adaptation, distribution and reproduction in any medium or format, as long as you give appropriate credit to the original author(s) and the source, provide a link to the Creative Commons license and indicate if changes were made.

Open Access This article is distributed under the terms of the Creative Commons Attribution 4.0 International License (http://creativeco mmons.org/licenses/by/4.0/), which permits unrestricted use, distribution, and reproduction in any medium, provided you give appropriate credit to the original author(s) and the source, provide a link to the Creative Commons license, and indicate if changes were made.
The original article can be found online at https://doi.org/10.1007/ s10086-006-0835-y.

\footnotetext{
Haruo Kawamoto

kawamoto@energy.kyoto-u.ac.jp

1 Department of Socio-Environmental Energy Science, Graduate School of Energy Science, Kyoto University, Yoshida Hon-machi, Sakyo-ku, Kyoto 606-8501, Japan
} 